\title{
STUDY OF HEPATITIS B VIRUS INFECTION AND ITS GENOTYPES IN TRIBAL PEOPLE
}

\author{
AMAL ALOTAIBI, JOHRA KHAN* \\ Department of Medical Lab Technology, College of Applied Medical Science, Majmaah University, Majmaah, Kingdom of Saudi Arabia. \\ Email: j.khan@mu.edu.sa \\ Received: 13 July 2016, Revised and Accepted: 02 January2017
}

\section{ABSTRACT}

Objective: This study was undertaken to screen the epidemiology of hepatitis B virus (HBV) in ethnically distinct, tribal dominated and of lower socioeconomic status area.

Methods: Briefly, $3 \mathrm{ml}$ blood was collected from 50 random liver disease cases with jaundice, receiving care at Central Hospital, N.F. Railway, Guwahati, and Guwahati Medical College, with informed consent. The patients detected with hepatitis A virus (HAV)-immunoglobulin M positive status were included and were stratified as acute viral hepatitis and fulminant hepatitis failure based on the clinical profile. HAV genotyping was studied by polymerase chain reaction-direct sequencing-phylogenetic analysis approach. Statistical analysis was performed using SPSS 13.0 software.

Result: A total of 50 cases were HBV infected. HBV infection was predominant in the young and adult age group. HBV-RNA was detected in 19 cases.

Conclusion: This study shows that HBV genotype D is most commonly found hepatitis in all tribes of Assam and poor sanitation and alcohol consumption are a common reason for its widespread.

Keywords: Genotype, Hepatitis B virus, Liver disease, Molecular epidemiology, Phylogenetic study.

(c) 2017 The Authors. Published by Innovare Academic Sciences Pvt Ltd. This is an open access article under the CC BY license (http://creativecommons. org/licenses/by/4. 0/) DOI: http://dx.doi.org/10.22159/ajpcr.2017.v10i4.14087

\section{INTRODUCTION}

Hepatitis B is a worldwide health-care problem, especially in developing areas. An estimated one-third of the global population has been infected with this virus approximately 350 million people are lifelong carriers and only $2 \%$ spontaneously seroconvert annually [12]. Ongoing vaccination programes appear to be promising in the attempt to decrease the prevalence of this disease [13]. Hepatitis B virus (HBV) is transmitted hematogenously and sexually. The outcome of this infection is a complicated viral-host interaction resulting in either an acute symptomatic disease or an asymptomatic disease. Patients may become immune to HBV or may develop a chronic carrier state. Later consequences are cirrhosis and the development of hepatocellular carcinoma (HCC) [14]. HBV belongs to the hepadnavirus family of enveloped DNA viruses containing a partially double stranded genome of $3182 \pm 3221$ bp depending on genotype that encodes four overlapping open reading frames as follows:

- $\quad \mathrm{S}$ for the surface or envelope gene encoding the pre-S1, pre-S2, and the $S$ protein

- C for the core gene, encoding for the core nucleocapsid protein and the e antigen

- $\mathrm{X}$ for the $\mathrm{X}$ gene encoding the $\mathrm{X}$ protein

- $\quad \mathrm{P}$ for the polymerase gene encoding a large protein promoting priming, RNA-dependent and DNA-dependent DNA polymerase and RNase $\mathrm{H}$ activities.

The genome is read in all three reading frames, and viral regulatory elements are all within coding regions which introduce constraints on the ability of the virus to accept mutations and remain viable [15]. Nevertheless, heterogeneityamong the strains of HBV circulating globally is $10 \%$-fold greater than that in the majority of DNA viral genomes. This is explained, at least partially, by the fact that hepadnavirus replication takes place via an RNA intermediate and reverse transcriptase is known to have a high error rate [16]. A nucleotide exchange rate of between 0-1 and 0-7 per year [17] has been estimated for the HBV [18] and woodchuck hepatitis virus [19]; genomes, respectively, which is similar to the most slowly evolving gene of retroviruses, the gag gene, and one to two orders of magnitude lower than the mutation rates previously calculated for the positive- and negative-strand RNA viruses [19]. The virus persists in $2-10 \%$ of adult patients and approximately $90 \%$ of infected infants leading to chronic liver disease. In highly endemic areas, infection is predominantly acquired during the perinatalneonatal period or by horizontal transmission in the first few years of life $[20,21]$ which results in a high prevalence of long-term HBV carriers with a low average age of infection [22]; the virus has a long time span in which to evolve within its host.

Hepatitis B is the major etiological cause of advance liver disease leading to HCC in India [1]. The seroprevalence of HBV, its different genotypes, and association with disease severity has been studied from different parts of India [2-9] excluding the Northeast; which may be a great underestimation of the HBV endemicity in India. Given that the population and indigenous tribes residing in Northeast are of different ethnicities than the rest of India and has a higher incidence of drug abusers as well as HIV infection, it is possible that the seroprevalence of $\mathrm{HBV}$ infection is very high in the North Eastern states.

\section{Natural history}

Acute infection with HBV in adulthood is rarely associated with the development of potentially fatal fulminant liver failure. Chronic infection, whether acquired in childhood or in adulthood, is associated with progressive liver disease; risk of cirrhosis, liver failure, and HCC; rarely with extrahepatic manifestations. Chronic HBV infection is characterized by four distinct phases: Immune tolerance, immune clearance, inactive carrier state, and reactivation [23]. The immune tolerance phase is characterized by detectable hepatitis B e antigen (HBeAg), high levels of HBV DNA ( $>105$ copies $/ \mathrm{mL}$ ), and normal alanine aminotransferase (ALT) levels. The immune clearance phase, also called chronic hepatitis $\mathrm{B}$, is characterized by detectable or undetectable HBeAg, undetectable or detectable anti-HBe antibodies, lower or fluctuating levels of HBV DNA, high or fluctuating ALT levels, and active inflammation as seen on liver biopsy. The inactive HBsAg carrier state is characterized by detectable HBsAg, undetectable HBeAg, detectable 
anti-HBe antibodies, low levels of HBV DNA $(<104$ copies/mL), and normal ALT levels $[10,11]$. Later in the carrier phase, HBsAg may become undetectable and anti-HBs antibodies may appear [23] although reactivation can occur in inactive HBV carriers.

\section{Epidemiology of $\mathrm{HBV}$}

HBV is a major public health problem worldwide. Approximately, 2 billion people worldwide have serological evidence of past or present HBV infection and 350 million people are chronically infected [1]. The prevalence of hepatitis B infection varies greatly throughout the world and is determined primarily by the predominant age at which the infection occurs. In areas where the prevalence is high, such as Southeast Asia, China, and Sub-Saharan Africa, more than half the population is infected at some time in their lives, and $10-20 \%$ are chronic carriers of the virus, the result of either neonatal transmission (vertical) or transmission from one child to another (horizontal). Risk of HBV infection continues after the first 5 years of life but its eventual contribution to the high rate of chronic infection is less significant. The risk of HCC is high in these areas. Areas with low levels of endemicity include North America, Western Europe, and Australia, where only a minority of people comes into contact with the virus, as a result of horizontal transmission among young adults. In intermediate-prevalence areas like the Mediterranean countries, Japan and India, the carrier rate is approximately $3-5 \%$. In these areas, there are mixed patterns of infant, early childhood, and adult transmission

In India, there are an estimated 42.5 million HBV carriers. In this group, transmission occurs in all the age groups, but early childhood infection accounts for most cases of chronic infection. The national average for chronic HBsAg positivity is $4.7 \%$ and around $24.4 \%$ of these patients are $\mathrm{HBeAg}$ positive and consequently highly infectious [24]. The HBV exposure rate has been estimated to range between $17 \%$ and $52 \%$ in the adult population. The HBsAg positivity below 1 year of age has been reported to range from $2.5 \%$ to $12.5 \%$ [25]. It is speculated that in $60 \%$ of subjects the HBV transmission occurs horizontally. HBV has been shown to be responsible for $26-62 \%$ of all sporadic acute viral hepatitis (AVH) illness and $22 \%$ of fulminant hepatic failure (FHF) in India. Nearly $60 \%$ of chronic liver disease in India is associated with HBV infection [2], as high as $80 \%$ of cases of cirrhosis of the liver are due to chronic HBV infection [26]. On the other hand, about $61.3 \%$ of patients with HCC seen at Chennai were positive for markers of HBV infection [27].

The exact epidemiology of HBV is important as the age at infection has significant impact on the clinical outcome because chronic infection occurs in approximately $90 \%$ of infected infants at birth, in $25-50 \%$ of children infected between the ages of 1 and 5 years, and in less than $5 \%$ of those infected during the adult life [24]. The World Health Organization estimates that the numbers of HBV carriers in the year 2000 are around 400 million.

\section{Modes of transmission}

$\mathrm{HBV}$ is a hardy virus with no animal reservoir. Man is the only known reservoir. Although HBsAg has been detected in urine, bile, tears, sweat, vaginal secretions, cerebrospinal fluid and synovial fluid, only serum, saliva, and semen are reported to be infectious. Respiratory, waterborne, or insect-related infections have not been documented. Before the screening of transfused blood was accepted universally, the risk of hepatitis B infection from transfusion of commercial blood was as high as $50 \%$. The exclusion of commercial donors and application of hepatitis B serological screening in the 1970s dramatically reduced the incidence of post-transfusion hepatitis B [28]. At present, the risk of transfusion-related hepatitis B from blood donors who test negative for HBsAg and anti-HBc is estimated to be in 1 in 63,000 . This risk can be further reduced by $42 \%$ by nucleic acid testing [29]. Now the common modes of transmission of HBV include sexual activity, injection-drug use, or occupational exposure. Other, less frequent causes of infection include household contact, hemodialysis, and receipt of organs or screened blood products. No clear risk factors are found in $20-30 \%$ of patients, perhaps because of a reluctance to report high-risk behavior or possibly mucosal or other unrecognized routes of infection [30]. Transmission of HBV parentally has also been described. The risk is greatest for infants born to women who are HBeAg positive and ranges from $70 \%$ to $90 \%$ at 6 months of age and $90 \%$ of these children remain chronically infected. The risk of perinatal infection among infants born to HBeAg-negative mothers ranges from $10 \%$ to $40 \%$, with $40-70 \%$ of these infected infants remaining chronically infected. Children born to HBsAg-positive mothers who do not become infected during the perinatal period remain at high risk of infection during early childhood. About $40 \%$ of infants born to HBeAg-negative mothers become infected by 5 years of age [30].

\section{HBV genotype}

$\mathrm{HBV}$ is classified into eight genotypes (A-H) that are geographically dispersed - Genotype A is predominant in North America, Western Europe, and Africa; genotypes B and C in Asia; genotype D in Southern Europe, Africa, and India; genotype $\mathrm{E}$ in West Africa; genotype $\mathrm{F}$ in Central and South America and Alaska; genotype G has been found in the United States, France, and Germany; genotype $\mathrm{H}$ in Central America. Genotypes A, B, C, and D predominate in the United States, while the other genotypes are less common [31]. Genotype B is associated with less active disease, slower progression, and lower incidence of HCC compared with genotype C. Genotypes A and B generally respond better to treatment with interferon than do genotypes $C$ and $D$. No relation between HBV genotypes and response to nucleos( $\mathrm{t}$ )ide analogue-based therapies has been demonstrated [31].

Originally, four genotypic groups of HBV (A-D) were defined based on an inter-genotypic divergence score of $8 \pm 5$ to $10 \pm 0 \%$ between 18 complete genomes, as compared to a score of $1 \pm 1-2 \pm 7 \%$ between isolates within the same genotype [32]. This genotypic classification was extended to six genotypes (A-F) by phylogenetic analysis of 122 surface antigen (HBsAg) genes [33]. The genotypic groups are geographically arranged [34] with genotypes $\mathrm{B}$ and C confined to Asia, while genotype A predominates in Northern Europe giving way to genotype D as one moves toward the Mediterranean region. Genotype E is mainly found in parts of East, Central, and West Africa and genotype F is only found in the New World and the Pacific which is also home to the Cq- subgroup of genotype C [35]. Two subgroups of genotype A, subgroups $\mathrm{A}$ and $\mathrm{A}$, were found in approximately equal amounts in an urban population from South Africa together with $10 \%$ of genotype D [36].

\section{HBV genotype and its association with severity of liver diseases} Studies from Southeast Asia have shown that HBV genotype C is associated with severe liver disease [38] and with lower rates of response to interferon-a, compared with rates of response associated with genotype B [39]. In Taiwanese patients, genotype B has been shown to be associated with the development of HCC at a younger age [40]. Differences among HBV genotypes in the rate of seroconversion to $\mathrm{HBe}$ antibody (anti-HBe) have been demonstrated in patients from Hong Kong [41]. In studies from Europe, differences among HBV genotypes in the selection of basal core promoter and/or precore mutations [42] and disease progression have been demonstrated [43].

A study from Northern India showed that HBV genotype D has been shown to be associated with more severe liver disease and may predict the occurrence of HCC in younger patients [44]. Genotype A was more often associated with ALT elevation, HBeAg positivity, absence of antiHBe and, among those aged 25 years and above, cirrhosis of liver, than was genotype D [45]. The frequency of mixed HBV genotypes has been reported to be $6 \%$ [39]. The clinical significance of HBV genotypes is becoming increasingly relevant. The identification of HBV genotypes may help in the early identification of potential sequelae after chronic HBV infection and may also help in implementation of appropriate therapeutic regimens in the North eastern states. 


\section{METHODS}

\section{Diagnostic criteria}

\section{Fulminant hepatitis failure (FHF)}

The diagnosis of FHF was considered when after a typical acute onset; the patient became deeply jaundiced and went into hepatic encephalopathy within 4 weeks of the onset of the disease with no history of pre-existing liver disease.

\section{AVH}

The patients of AVH will be evaluated on the basis of clinical and biochemical features of acute hepatocellular disease untreated to any toxic or drug etiology. The liver function test (LFT) suggested hyperbillirubinia, rise in transaminase level.

\section{Chronic hepatitis}

Chronic hepatitis will be diagnosed as per AASLD practice guideline (Lok et al., 2001):

1. HBsAg positive $>6$ months

2. Serum HBV DNA $\geq 10^{5}$ copies $/ m L$ for $H B e A g+v e$ Ch-B and $\geq 10^{4}$ copies $/ \mathrm{mL}$ for HBeAg -ve Ch-B

3. Persistent or intermittent elevation in ALT/aspartate aminotransferase levels

4. Liver biopsy showing chronic hepatitis (necroinflammatory score $\geq 4$ ).

Liver histology of HBV related disease severity will be assessed by modified version of the Knodell histological activity index (Ishak et al., 1995) and the French METAVIR score (Bedossa et al., 1996 and Brunt, 2000).

\section{Cirrhosis}

The diagnosis of cirrhosis will be considered on the basis criteria:

i. Ascites, splenomegaly, shrunken liver

ii. Endoscopy shows esophageal varices

iii. Biochemical features of hepatocellular failure, characterized by low serum albumin level $(<2.5 \mathrm{~g} \%)$, increased BSP (Bilirubin serum Protein) retention of more than $16 \%$

iv. Liver biopsy will be done to substantiate the diagnosis whenever feasible

v. The presence of activity will be decided on the basis of raised serum bilirubin (moderate elevation of bilirubin up to $5 \mathrm{mg}$ ) and raised transaminases (3-5 times than normal)

vi. Liver biopsy is suggestive of activity, when it demonstrates evidence of focal cellular necrosis and mononuclear cell in filtration into the portal tracts as well as in to hepatic lobules.

HCC

The EASL diagnostic criteria for the diagnosis of HCC will be followed (Bruix et al. 2001). Diagnostic criteria for HCC will be based on either fine-needle aspiration cytology or any two of the following inclusion criteria:

- Alpha fetoprotein (AFP) more than $400 \mathrm{ng} / \mathrm{ml}$

- Arterialization on color Doppler

- Arterialization of triple-phase computed tomography (TPCT)

- Arterialization on contrast enhanced magnetic resonance imaging (MRI) (Contrast enhanced MRI will be used in the rare occasions [ESAL criteria: Bruix et al., 2001] when diagnosis could not be founded by US, TPCT and AFP).

\section{Inclusion criteria}

All those patients who will be clinically diagnosed as AVH, FHF, chronic active hepatitis, cirrhosis, HCC will be included in the study. Voluntary blood donors and health-care workers will be included in this study.

\section{Exclusion criteria}

Professional blood donors, high risk group like intravenous drug abusers will be excluded from the study.

\section{MATERIAL AND METHOD}

The patients of AVH were evaluated based on history and clinical examination. The LFTs will be done at first visit. The patients of AVH, FHF will be evaluated based on history, physical examination, LFT, and serological test for HBsAg. Samples, which are positive for HBsAg, will also be screened for immunoglobulin M (IgM) anti-HBc and HBV-DNA. To rule out any coinfection with other hepatotropic viruses IgM antihepatitis A virus, anti-hepatitis C virus (HCV), IgM, anti-HEV infection will also be carried out. The patients of chronic liver disease, viz., chronic hepatitis, cirrhosis of liver, and HCC will be also evaluated based on history, physical examination, liver function profile, prothrombin time, serological markers for HBsAg. Samples which are positive for HBsAg will be further tested for IgG anti-HBc and HBeAg followed by HBV DNA. Anti-HCV and HCV RNA will be done in the cases which are positive for HBV DNA to rule out cases of coinfection.

The serum of voluntary blood donor was collected from blood banks Medical Institution of NE India. These blood donors were evaluated based on a preform and their LFTs was done. They will be screened for HBsAg using commercially available enzyme-linked immunosorbent assay (ELISA) kits ( $3^{\text {rd }}$ generation) at each center. Those samples of blood donors, who are found positive for HBsAg, shall be reported and despatch to the respective reference laboratory, viz., Gauhati University, Department of Applied Sciences, with regard to molecular biology works.

\section{Extraction of HBV DNA}

Isolation of DNA from serum

From each serum sample, $300 \mathrm{ml}$ will be incubated at $65^{\circ} \mathrm{C}$ for $4 \mathrm{hrs}$ in $20 \mathrm{mM}$ Tris- $\mathrm{HCl}(\mathrm{pH} 8.0)-10 \mathrm{mM}$ EDTA - 0.1\% sodium dodecyl sulfate $-0.8 \mathrm{mg}$ of proteinase $\mathrm{K}$ per $\mathrm{ml}$. The DNA was then extracted with phenol, subsequently extracted with chloroform, and precipitated

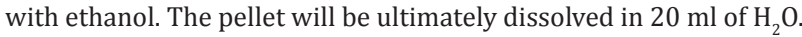

\section{Polymerase chain reaction (PCR) amplification of HBV DNA} Surface gene amplification

Part of the surface gene (nucleotide position 425 to position 840) will be amplified by nested PCR. $3 \mu \mathrm{l}$ of extracted DNA from sera samples will be used as template. The amplification step will be performed for 30 cycles with the outer primers 5'-ATCGCTGGATGTGTCTGCGG-3' and 5'-GGCAACGGGGTAAAGGTTCA-3' $10 \mu \mathrm{l}$ of amplified product will be analyzed on $1.2 \%$ agarose gel in $\times 1$ tris/borate/EDTA (TBE). Samples, which will not show amplification, would be directly used for nested amplification. Where 787 bp fragment will be generated, nested PCR will be done after appropriate dilution. $3 \mu \mathrm{l}$ of the first round PCR product (directly or after dilution depending on the band intensity visualized on the gel) will be used as a template in the second amplification step performed for 30 cycles with inner primers 5'-TTAGGGTTTAAATGTATACCC-3' and 5'-CATCTTCTTGTTGGTTCTTCTG-3'. $10 \mu \mathrm{l}$ of nested PCR product ( $416 \mathrm{bp}$ ) will be analyzed by the agarose gel electrophoresis on $1.2 \%$ gel in $\times 1$ TBE or tris base, acetic acid and EDTA buffer.

\section{Pre-core and core-gene amplification}

The amplification of core promoter, precore, and core genes will be performed using 5'CATAAGAGGACTCTTGGACT3' and 5'GGCGAGGGAGTTCTTCTTC3'. The amplification of 742 bp will be checked for on $1.2 \%$ agarose gel.

\section{Type specific primer for $\mathrm{HBV}$ genotyping} Genotyping of $H B V$

HBV genotypes were determined by multiplex PCR, i.e., surface region designed by Oliver et al. Briefly, $5 \mu \mathrm{L}$ of extracted HBV DNA was subjected to PCR using primers used by Oliver et al. The size of the expected genotype specific amplification is: Genotype A $370 \mathrm{bp}$, genotype B $190 \mathrm{bp}$, genotype C 701 bp, genotype D $147 \mathrm{bp}$, genotype E $787 \mathrm{bp}$, and genotype $\mathrm{F} 481 \mathrm{bp}$. 


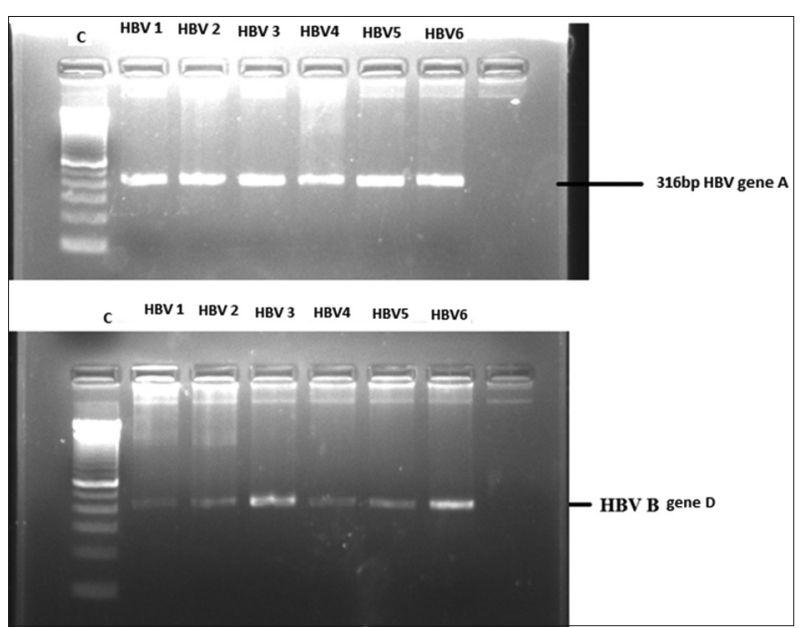

Fig. 1: Polymerase chain reaction amplification results. ( $a$ and b) Hepatitis B virus (HBV) genotyping results, where an amplicon of $316 \mathrm{bp}$ represents $\mathrm{HBV}$ gene $\mathrm{A}$. The HBV were purified by gel extraction and subjected to direct sequencing for genotype determination on comparison with the standard NCBI representative sequences for hepatitis $C$ virus and hepatitis $E$ virus

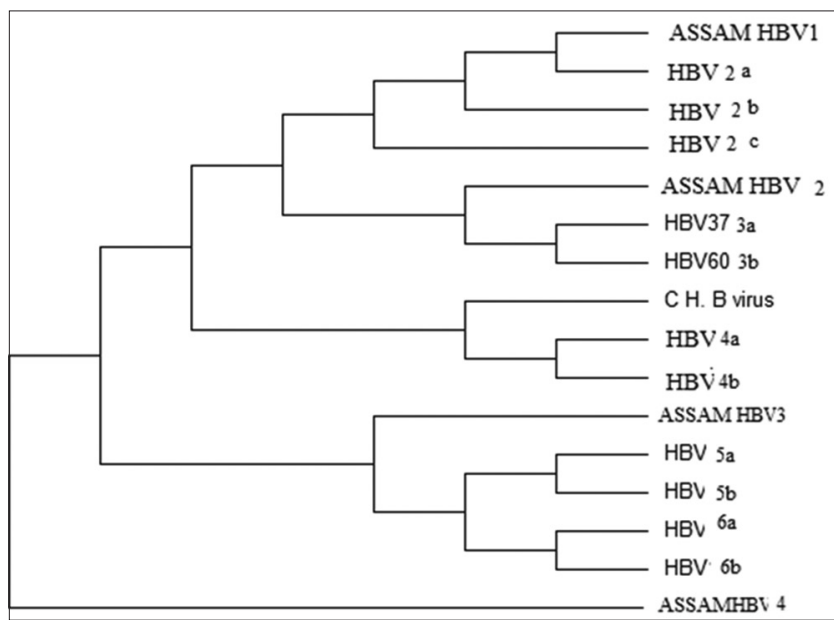

Fig. 2: Phylogenetic analysis using the Expasy software tool. Randomly sequenced hepatitis B virus (HBV) cases representing HBV genotype D (ASSMHBV1) to (ASSMHBV4) by multiplex polymerase chain reaction genotyping, therefore confirming and validating our genotyping results

Sequencing of the surface, basal core, precore and the core region of $H B V$

Representative cases of the PCR amplified product of core promoter, pre-core and core region (742p fragment) and surface region (416) will be purified using the gel extraction method (Qiagen gel extraction kit) and will be subjected to sequencing. The sequencing will be done for checking the presence of viral mutations in the surface and basal core promoter, precore, and the core region of $\mathrm{HBV}$ as well as for the validation of the genotyping results by multiplex PCR.

\section{RESULTS AND DISCUSSION}

Blood samples were collected from patients with liver disease who were receiving care in regional referral hospitals in Guwahati. These patients had a median age of $40 \pm 16$ years and showed a male to female ratio of $10: 1$. The majority of the liver disease patients were male $31 / 50$, $62 \%)$. The hepatitis virus infection spectrum analyzed based on IgM ELISA results was $\operatorname{HBV}(19 / 50,38 \%)$ and coinfection $(3 / 50,6 \%)$.
Others had alcoholic $(12 / 50,24 \%)$ and cryptogenic $(16 / 50,32 \%)$ liver disease.

\section{Viral genotyping}

Viral genotyping was performed for HBV samples. Genotyping was performed by multiplex PCR. HBV genotype D $(16 / 19,59.1 \%)$ was the most prevalent in the HBV-positive cases (Fig. 1). A few of the randomly selected genotyped samples were crosschecked and validated by direct sequencing of the core region of HBV followed by phylogenetic analysis. The nucleotides that were sequenced by direct sequencing were aligned using ClustalW, and version 1.6 of the tree view program from MEGA (6) was then used to construct an uprooted phylogenetic tree (Fig. 2). After comparison with known sequences from the NCBI Genbank database, the distribution of the genotypes based 4 isolated HBV (ASSAMHBV1, ASSAMHBV2, ASSAMHBV3, and ASSAMHBV4) was found to be one each from genotypes.

\section{DISCUSSION}

Along with age, sex and viral factors, alterations in host genetic factors and environmental factors are also considered important in the development of liver disease, but unfortunately, there are very limited data available on these important aspects in liver disease patients from Northeast India, who are ethnically distinct from those in other parts of the country. The highest prevalence of fecal-oral infection occurs in regions where standards of sanitation and higher alcohol consumption low. Alcohol consumption is well entrenched in the social fabric of many adult populations, virtually constituting a behavioral norm. The level of alcohol consumption in a population is an important determinant of health and social well-being (Rehm J et al., 2009). Widespread and increasing use of alcohol is drawing attention to the health consequences of alcohol consumption. Alcohol-related liver disease is a significant burden on health, with alcohol consumption accounting for an estimated 3.8\% of global mortality [46]. Alcohol is a major cause of liver cirrhosis in the Western world. Alcoholic cirrhosis is increasingly seen in countries such as Japan and India, which traditionally had a low prevalence of the disease [47]. In our studies, we found that the adult who are more exposed to poor sanitation and use more alcohol the chances of spread of $\mathrm{HBV}$ is more (21.43\%). The burden of alcohol related liver disease is likely to be higher in the future as indicated by our results which showed that an alcohol related liver disease cases are predominant in the younger age group of 11-40 years, since the consumption of alcohol is been taken up in the early phase of life in northeast India; moreover, it is customary to consume alcohol in several tribal groups of Assam and northeast India. Larger studies in various populations are required to explore further the link between the innate and adaptive immune systems in relation to HBV infection, in an attempt to identify additional susceptibility loci and indications of the initiator of the disease.

\section{REFERENCES}

1. Kumar M, Kumar R, Hissar SS, Saraswat MK, Sharma BC, Sakhuja P, et al. Risk factors analysis for hepatocellular carcinoma in patients with and without cirrhosis: A case-control study of 213 hepatocellular carcinoma patients from India. J Gastroenterol Hepatol 2007;22(7):1104-11.

2. Acharya SK, Madan K, Dattagupta S, Panda SK. Viral hepatitis in India. Natl Med J India 2006;19(4):203-17.

3. Chowdhury A, Santra A, Chakravorty R, Banerji A, Pal S, Dhali GK, et al. Community-based epidemiology of hepatitis B virus infection in West Bengal, India: Prevalence of hepatitis B e antigen-negative infection and associated viral variants. J Gastroenterol Hepatol 2005;20(11):1712-20.

4. Kurien T, Thyagarajan SP, Jeyaseelan L, Peedicayil A, Rajendran P, Sivaram S, et al; STD study group.community prevalence of hepatitis $\mathrm{B}$ infection and modes of transmission in Tamil Nadu, India. Indian J Med Res 2005;121(5):670-5.

5. Banerjee A, Chakravarty R, Mondal PN, Chakraborty MS. Hepatitis $B$ virus genotype $D$ infection among antenatal patients attending a maternity hospital in Calcutta, India: Assessment of infectivity status. Southeast Asian J Trop Med Public Health 2005;36(1):203-6. 
6. Murhekar MV, Murhekar KM, Sehgal SC. Seroepidemiology of hepatitis B infection among tribal school children in Andaman and Nicobar Islands, India. Ann Trop Paediatr 2004;24(1):85-8.

7. Singh H, Aggarwal R, Singh RL, Naik SR, Naik S. Frequency of infection by hepatitis B virus and its surface mutants in a northern Indian population. Indian J Gastroenterol 2003;22(4):132-7.

8. Ganju SA, Goel A. Prevalence of HBV and HCV infection among health care workers (HCWs). J Commun Dis 2000;32(3):228-30.

9. Chowdhury A, Santra A, Chaudhuri S, Ghosh A, Banerjee P, Mazumder DN. Prevalence of hepatitis B infection in the general population: A rural community based study. Trop Gastroenterol 1999;20(2):75-7.

10. Blumberg BS, Alter HJ, Visnich S. Landmark article Feb 15, 1965: A "new" antigen in leukemia sera. By Baruch S. Blumberg, Harvey J. Alter, and Sam Visnich. JAMA 1984;252(2):252-7.

11. Dane DS, Cameron CH, Briggs M. Virus-like particles in serum of patients with Australia-antigen-associated hepatitis. Lancet 1970;1(7649):695-8.

12. Pungpapong S, Kim WR, Poterucha JJ. Natural history of hepatitis B virus infection: An update for clinicians. Mayo Clin Proc 2007;82(8):967-75.

13. Shen LP, Yang JY, Mo ZJ, Li RC, Li YP, Wei ZL, et al. Variations of hepatitis B virus infection epidemic pattern after long-term HBV vaccine immunization. Zhonghua Shi Yan He Lin Chuang Bing Du Xue Za Zhi 2007;21(3):253-5.

14. Chu CM. Natural history of chronic hepatitis B virus infection in adults with emphasis on the occurrence of cirrhosis and hepatocellular carcinoma. J Gastroenterol Hepatol 2000;15 Suppl: E25-30.

15. Yang Z, Lauder IJ, Lin HJ. Molecular evolution of the hepatitis B virus genome. J Mol Evol 1995;41:587-96.

16. Boyer JC, Bebenek K, Kunkel TA. Unequal HIV-1 reverse transcriptase error rates with RNA and DNA templates. Proc Natl Acad Sci USA 1992;89:6919-23.

17. Gunther S, Fischer L, Puli I, Sterneck M, Will H. Naturally occurring variants of hepatitis B. In: Maramorosch K, Murphy FA, Shatkin AJ, editor. Advances in Viral Research. San Diego: Academic Press; 1999. p. $25-137$

18. Okamoto H, Imai M, Kametani M, Nakamura T, Mayumi M. Genomic heterogeneity of hepatitis B virus in a 54-year-old woman who contracted the infection through materno-fetal transmission. Jpn J Exp Med 1987;57:231-6.

19. Girones R, Miller RL. Mutation rate of the hepadnavirus genome. Virology 1989;170:595-7.

20. Beasley RP, Hwang LY. Epidemiology of hepatocellular carcinoma. In: Vyas GN, Dienstag JL, Hoofnagle JH. Viral Hepatitis and Liver Disease. Orlando, FL: Grune and Strattonl; 1984. p. 209-24.

21. Botha JF, Dusheiko GM, Ritchie MJ, Mouton HW, Kew MC. Hepatitis $B$ virus carrier state in black children in Ovamboland: Role of perinatal and horizontal infection. Lancet 1984;1:1210-2.

22. Edmunds WJ, Medley GF, Nokes DJ, O'Callaghan CJ, Whittle HC, Hall AJ. Epidemiological patterns of hepatitis B virus (HBV) in highly endemic areas. Epidemiol Infect 1996;117:313-25.

23. Yim HJ, Lok AS. Natural history of chronic hepatitis B virus infection: What we knew in 1981 and what we know in 2005. Hepatology 2006;43 2 Suppl 1:S173-81.

24. Chandra R, Kapoor D, Agarwal SR, Malhotra V, Sakhuja P, Sarin SK. Profile of asymptomatic chronic HBV infection in India. Indian J Med Res 2002;116:50-7.

25. Satapathy SK, Garg S, Chauhan R, Malhotra V, Sakhuja P, Sharma BC, Sarin SK. Profile of chronic hepatitis B virus in children in India: Experience with 116 children. J Gastroenterol Hepatol 2006;21(7):1170-6.

26. Nayak NC, Dhar A, Sachdeva R, Mittal A, Seth HN, Sudarsanam D, et al. Association of human hepatocellular carcinoma and cirrhosis with hepatitis B virus surface and core antigens in the liver. Int J Cancer
1977;20(3):643-54.

27. Tandon BN, Acharya SK, Tandon A. Epidemiology of hepatitis B virus infection in India. Gut 1996;38 Suppl 2:S56-9.

28. Alter HJ, Holland PV, Purcell RH, Lander JJ, Feinstone SM, Morrow AG, et al. Posttransfusion hepatitis after exclusion of commercial and hepatitis-B antigen-positive donors. Ann Intern Med 1972;77(5):691-9.

29. Liu CJ, Chen DS, Chen PJ. Epidemiology of HBV infection in Asian blood donors: Emphasis on occult HBV infection and the role of NAT. J Clin Virol 2006;36 Suppl 1:S33-44

30. Margolis HS, Alter MJ, Hadler SC. Hepatitis B: Evolving epidemiology and implications for control. Semin Liver Dis 1991;11(2):84-92.

31. Lok AS, McMahon BJ. Chronic hepatitis B. Hepatology 2007;45(2):507-39.

32. Okamoto H, Tsuda F, Sakugawa H, Sastrosoewignjo RI, Imai M, Miyakawa Y, et al. Typing hepatitis B virus by homology in nucleotide sequence: Comparison of surface antigen subtypes. J Gen Virol 1988;69:2575-83.

33. Norder H, Hammas B, Lee SD, Bile K, Courouce AM, Mushahwar IK, et al. Genetic relatedness of hepatitis B viral strains of diverse geographical origin and natural variations in the primary structure of the surface antigen. J Gen Virol 1993;74:1341-8.

34. Magnius LO, Norder H. Subtypes, genotypes and molecular epidemiology of the hepatitis B virus as reflected by sequence variability of the S-gene. Intervirology 1995;38(1-2):24-34

35. Norder H, Courouce AM, Magnius LO. Complete genomes, phylogenetic relatedness, and structural proteins of six strains of the hepatitis B virus, four of which represent two new genotypes. Virology 1994; 198:489-503.

36. Bowyer SM, van Staden L, Kew MC, Sim JG. Aunique segment of the hepatitis B virus group A genotype identified in isolates from South Africa. J Gen Virol 1997;781719-29.

42. Kao JH, Chen PJ, Lai MY, Chen DS. Genotypes and clinical phenotypes of hepatitis B virus in patients with chronic hepatitis B virus infection. J Clin Microbiol 2002;40(4):1207-9.

43. Kao JH, Wu NH, Chen PJ, Lai MY, Chen DS. Hepatitis B genotypes and the response to interferon therapy. J Hepatol 2000;33(6):998-1002.

44. Kao JH, Chen PJ, Lai MY, Chen DS. Hepatitis B genotypes correlate with clinical outcomes in patients with chronic hepatitis B. Gastroenterology 2000;118(3):554-9.

45. Chu CJ, Hussain M, Lok AS. Hepatitis B virus genotype B is associated with earlier $\mathrm{HBe} \mathrm{Ag}$ seroconversion compared with hepatitis $\mathrm{B}$ virus genotype C. Gastroenterology 2002;122:1756-62.

46. Grandjacques C, Pradat P, Stuyver L, Chevallier M, Chevallier P, Pichoud $\mathrm{C}$, et al. Rapid detection of genotypes and mutations in the pre-core promoter and the pre-core region of hepatitis B virus genome: Correlation with viral persistence and disease severity. J Hepatol 2000;33(3):430-9.

47. Sánchez-Tapias JM, Costa J, Mas A, Bruguera M, Rodés J. Influence of hepatitis B virus genotype on the long-term outcome of chronic hepatitis B in Western patients. Gastroenterology 2002;123(6):1848-56.

48. Kar P, Polipalli SK, Chattopadhyay S, Hussain Z, Malik A, Husain SA, et al. Prevalence of hepatitis B virus genotype D in pre-core mutants among chronic liver disease patients from New Delhi, India. Dig Dis Sci 2007:52(2):565-9.

49. Kumar A, Kumar SI, Pandey R, Naik S, Aggarwal R. Hepatitis B virus genotype $\mathrm{a}$ is more often associated with severe liver disease in Northern India than is genotype D. Indian J Gastroenterol 2005;24(1):19-22.

50. Rehm J, Mathers C, Popova S, Thavorncharoensap M, Teerawattananon Y, Patra J. Global burden of disease and injury and economic cost attributable to alcohol use and alcohol-use disorders. Lancet 2009;373(9682):2223-33.

51. Walsh K, Alexander G. Alcoholic liver disease. Postgrad Med J 2000;76:280-6. 